\title{
Applied Aspects of Humus Balance Modelling in the Rivne Region of Ukraine
}

\author{
Petro Skrypchuk ${ }^{1}$, Viktor Zhukovskyy ${ }^{1{ }^{*}}$, Halyna Shpak ${ }^{1}$, \\ Nataliia Zhukovska', Halyna Krupko \\ 1 National University of Water and Environmental Engineering, Soborna str. 11, Rivne, 33028, Ukraine \\ 2 Rivne Branch of the Soils Protection Institute of Ukraine, Rivnenska str. 3, Shubkiv, 35325, Ukraine \\ * Corresponding author's e-mail:v.v.zhukovskyy@nuwm.edu.ua
}

\begin{abstract}
The balance calculations in agriculture are the basis for assessing the value of land and determining how to use it effectively. Replenishing the humus balance in soils is a long and multifactorial process, and therefore requires considerable expenditures to control it. Therefore, scientists pay particular attention to the benefits and the need to create geoinformation portals, first and foremost, in the agricultural sector in order to create effective market-based tools for balancing soil quality. However, today Ukraine has little experience in creating portals and software for the implementation of soil fertility balance calculations in the online system for the purpose of organizing organic land use. The article deals with the methods of humus balance calculation and the formulation of the humus balance calculation task, which will take into account regional peculiarities of Ukraine's Rivne region with the possibility of scaling to other areas. A mathematical model of the corresponding problem using differential equations was constructed. A numerical solution was found and implemented as the e-calculator module of online information system. The integration of IT technologies with the example of humus balance e-calculator for organic land use will allow crop rotations modeling and volumes of organic fertilizer application to stabilize or improve the soil quality. The main task of the calculator was to provide specific recommendations for the land plot on the efficiency of its use. In addition, the information system provided the background information on the economic efficiency of the transition to organic farming, certification, processing and marketing rules. The user can independently specify the order of crops cultivation in rotation, the amount of organic fertilizer application and as a result will receive the possible variants of the total humus content in the soil, for different volumes of application of organic fertilizers (biohumus) using the e-calculator of humus balance. The testing and verification of the e-calculator was carried out on the last 40 years data of the Rivne branch of the Soils Protection Institute of Ukraine, taking into account the cultivated crops, the introduction of mineral and organic fertilizers.
\end{abstract}

Keywords: humus balance, e-calculator, mathematical model, organic land use, crop rotation variants modeling, soil quality improvement, biohumus, organic portal.

\section{INTRODUCTION}

In the agriculture of Ukraine and the Rivne region, in particular, the problem of rational land use and protection, conservation and reproduction of soil fertility have been increasing over the last two decades.

The consequence of the negative processes is the agricultural land fertility decrease. Over the last 20 years, the system of agricultural land use has been destroyed, which included the introduction of a crop rotation system, a deficient balance of humus and nutrients and a soil protection system of agriculture.

A prerequisite for efficient utilization of agricultural land, improved production efficiency and risk reduction is and will be monitoring the information on the changes in their fertility and environmental status as a whole. Modern monitoring is performed with the use of geoinformation and IT technologies in almost all technological processes of the agro-industrial sector (Skrypchuk, 
2018a, 2018b; Vlasyuk et al., 2018a; Pichura et al., 2019; Skrypchuk, 2019; Skrypchuk et al., 2020).

The total area of Ukraine is 60.3 million hectares, agricultural land -41.5 million hectares, arable land - 32.7 million hectares. Favorable land-resource conditions Ukraine are largely due to the soil cover, which in more than $70 \%$ consists of potentially fertile soils, including chernozems and meadow-chernozem soils, which are characterized by high levels of natural fertility.

For 130 years, since the first measurements of the humus content in the ukrainian soils made by V.V. Dokuchaev, the humus losses in the forest-steppe soils averaged $22 \%$, in the steppe soils $-19.5 \%$ and in the Polesie soils - about $19 \%$. The greatest losses of humus occurred in the 1970 s, when the share of crop crops, i.e. sugar beet and sunflower, rose sharply in the crop structure. However, in the 1980 s, the loss was managed to be stopped due to the annual average use of $8.4 \mathrm{ton} / \mathrm{ha}$ manure and about $170 \mathrm{~kg}$ mineral fertilizers per 1 ha of arable land, and in some areas even higher - 15 ton/ha and more than $200 \mathrm{~kg}$ a.d., respectively. It was during these years that simple reproduction of fertility was achieved in the soil of Ukraine, that is, a deficit-free balance of the basic nutrients and humus was formed.

At the same time, a number of scientists have been engaged in the issues of humus balance modeling (Leithold et al., 1997; Kolbe, 2010; Franko et al., 2011; Heitkamp et al., 2011; Brock et al., 2012; Brock et al., 2013; Schulz et al., 2014; Brock et al., 2015; Campbell et Paustian, 2015; Vlasyuk et al., 2018b; Shostak et al., 2019; Vlasyuk et al., 2020b; Vlasyuk et al., 2020a). They laid down the basic definitions and principles for calculating the humus balance.

In order to predict the change in the soil organic matter (SOM) levels over a long period, the dynamics of organic matter are simulated. The first published model of OPE decomposition based on differential equations was proposed by S. Genin and his colleagues (Hénin et Dupuis, 1945). One of the most popular SOM dynamics models today is Rothamsted (RothC), which emits 4 active pools and 1 stable pool (inert organic matter) (Hénin et Dupuis, 1945). In the post-Soviet space, the widespread model of ORU dynamics (ROMUL) involves the allocation of three major pools - detritus (prehumus fraction), labile humus, and stable humus (Chertov et al., 2001).

The balance calculations in agriculture are the basis for estimating the conditions of humus accumulation. They enable to control soil replenishment with fresh organic matter, to predict the changes in the humus state, and to regulate the processes of soil organic matter transformation. This is a rather complicated process that is influenced by many factors, including:

- soil type and natural area;

- use of plant residue;

- volumes of application and type of organic fertilizer;

- fertilizer systems;

- structure of rotation;

- soil tillage (plowing, plowing) (Skrylnik et al., 2017);

- type and intensity of agricultural land use (Chaban et al., 2010);

- soil calcification (Oliver et al., 2014).

Not all of these factors take into account the current methods of calculating the humus balance. This is partly due to the complexity of mathematical calculations. Therefore, it is important today to direct further activities of specialists to the development and implementation of software systems (computer models) for the evaluation of the humus balance, and more precisely - all dynamics of the humus soil condition with maximum consideration of all factors.

In addition, many scientists have emphasized that an important factor in the effectiveness of the agricultural production development, including organic production, is the introduction of innovative management approaches based on geoinformation systems (GIS). The features of the GIS use in the agricultural sector, including organic farming, presented by such scientists as: Medvedev V.V. (2007), Romashchenko M.I. et al. (2005), Morozov V.V. et al. (2007), Lisetskii et al. (2017), Jaafar and Woertz (2016), Montgomery et al. (2016), Mishra et al. (2015), Oumenskou et al. (2018) and other scientists.

Particular attention is paid to the benefits and the need to create the geoinformation portals for all sectors of the economy, especially in the agricultural sector. Bernard et al. (2005) and Maguire and Longley (2005) emphasized that the creation of a geo-portal would ensure consistency with many public institutions through the online access to spatial data sets and thematic services to create an effective mechanism for their interaction. Considerable opportunities for using the geo-portal based on the geoinformation-analytical systems in the agrarian sector are presented in 
Tait (2005). However, today in Ukraine there is no experience in creating sites, portals, software products for online settlement in order to organize organic land use that will provide convenient access to the necessary space-time information.

\section{MATHERIAL AND METHODS}

\section{Humus balance calculating}

The term humus balance encompasses both simple models for quantifying soil organic matter (SOM) changes in arable soils, or soil organic carbon (C) (SOC) in particular, and the model related to optimizing the soil productivity in arable land by calculating the demand for organic fertilizers without quantifying the change in SOM or SOC.

In the world practice, the methods of calculating the humus balance in soils are divided into agronomic and ecological (Brock et al., 2013). The ecological ones take into account the soil properties, climate features, agrotechnical measures and aim to quantify the changes in the humus content in soil (HU-MOD, STAND, CCB). In turn, the agronomic methods are insensitive to the changes in environmental factors and are based on inputs and losses of soil organic matter (VDLUFA, Humus Unit, Dynamic Humus Unit, SALCA). Their task is to determine the need for agrotechnical measures to maintain balance.

In the ROMUL model mentioned above, the OR (carbon) dynamics are recovering well and the nitrogen behavior is satisfactory. To date, a significant number of dynamic simulation models have been developed for the soils of agro- and natural (forest and steppe) ecosystems, which differ significantly in their theoretical justification (Manzoni and Porporato 2009). In the OR models of agroecosystems, the dynamics of the OR horizon is largely reproduced. In the OR models of different genesis soils of natural ecosystems, there is an organic and humus-accumulative horizon or a fixed part of the soil profile. In most soil ORG models, microorganisms are the sole agent of ORG transformation. Only two models take into account the humus-forming role of the soil fauna in a very generalized form. This is the ROMUL-EFIMOD model (Chertov et al., 2001) and the model family (Kätterer and Andrén 2001). In the existing models of soil micro- and mesofauna, no attention is paid to the processes of the humic substances formation. In this regard, the most important are the realistic description when modeling the entire soil profile. The vast majority of ORG models lack an organic horizon. In the ROMUL model, the organic horizon was generally considered as forest floor and only in Romul_Hum was the floor represented by all three horizons.

The agronomic methods of calculating the humus balance are common in Ukraine. For the chernozem soils, the techniques proposed by Gnatenko et al. (2005) and Baluk et al. (2011), based on determining the difference between the articles of receipt and humus loss in the same period of time, and are calculated on the basis of the data on the organic fertilizers amount and plant residues entering the soil, with the corresponding coefficients of humification and annual average humus. According to Hrekov and Datsko (2009) the soil type, groups of crops, and climatic conditions are additionally taken into account when determining the humus mineralization. A separate article takes into account the humus losses due to the soil erosion.

The method of calculating the humus balance proposed by Lykov (1979) for the sod-podzolic soils of the Polissia crop rotations is somewhat more complicated. The basis for this method is the nitrogen balance in the system "plant - soil - fertilizer". They shift from the nitrogen balance to the humus carbon balance, taking into account the ratio between carbon and nitrogen in the humus as 10: 1 (Lykov 1979).

In order to automate the calculating process of the balance of humus and mobile nutrients in soils, specialists of the National Scientific Center "Institute of Soil Science and Agrochemistry named after O.N. Sokolovsky" computer program was developed, which allows determining the balance of soil humus at the area level, district, economy, crop rotation (Baluk et al., 2011).

Organic land management aims at maintaining the natural soil fertility. Plant nutrition must flow through the soil ecosystem. In doing so, the use of fertilizers and non-renewable plant nutrition should be minimized. Among the main measures for the systematic flow of fresh organic matter into the soil and the mobile humus formation, which do not contradict organic standards, are the application of organic fertilizers, the use of plant residues and non-market production part, regular cultivation in green manure crop rotation, legumes or herbs. 
According to many agrochemical scientists, the diversity and effectiveness of soil and plant effects on the crop rotation factor outweigh other equally important measures. Their impact is related to many soil processes and various aspects of plant growth and development. The crop rotation is planned to support biodiversity, provide reliable protection against pests and diseases, help preserve the basic soil properties, manage soil structure and increase its fertility naturally. Crop rotations include cereals and industrial crops, perennial grasses and necessarily siderata.

According to the rules of organic farming under the perennial legumes crops- clover, alfalfa, asparagus, clover and others. should be at least $35-40 \%$ of the acreage. They determine the possibility of introducing different forms of green manure. Green fertilizers in the main and intermediate crops should be $20-25 \%$ with the obligatory use of cereals and legumes crushed straw, corn and sunflower, beetroot crushed stalks.

The important role of crop rotation, as an agronomic measure that helps to ensure a proper level of crop yield, is also emphasized by Boyko et al. (2018). Separate theoretical and practical aspects of the use in the green manure rotation and plant residues are devoted to the work of scientists, in particular: Degodyuk E.G., Litvinova O., Shevchuk M.I., Medvedev V.V., Plisko I.V., Bogdanovich R.P., Oliynyk V.S. and others.

It was established that quantitative indices of humus reproduction process are dependent on the composition, ratio and productivity of crops in crop rotation. These factors determine the average yield of dry organic mass of plant residues, which are the main source of replenishment of organic substances necessary for the synthesis and mineralization of humus under the influence of different groups of microorganisms. By changing the ratio of area under different plants, it is possible to increase to some extent the inflow of fresh organic matter into soil with plant residues (Bogdanovich and Oliynyk 2014).

Studies have proven that the systematic incorporation of the biomass by-products of crop rotations into the soil, even without the application of mineral fertilizers, can provide a deficit-free balance of humus (Lebid and Tsylyuryk 2014).

Volkogon et al. (2016) emphasized that siderata constitute a source of carbon and energy with minimal costs (for seeds and processing operations related to cultivation and grounding). According to Baluk et al. (2011), the efficiency of green manure in the humus compounds synthesis is equivalent to $25 \%$ of the bedding manure effect. On the other hand, Litvinova (2020), relying on the results of field studies (on sod-podzolic soils), states that long-term use of the nutrient green manure increases the organic matter intake by $32 \%$, carbon - by $58 \%$, and the straw carbon content increases to $87 \%$ with straw. The combination of straw and green manure agrotechnical measures prevents the unnecessary nitrogen and organic matter losses due to intensive mineralization and narrows the $\mathrm{C}: \mathrm{N}$ ratio to the optimal values, providing better conditions for the humification of organic matter (Litvinova, 2020).

Biohumus is selected as an organic fertilizer for several reasons. First, according to the requirements of organic standards, the waste and by-products of plant and animal origin must be recycled to further feed the plants. Biohumus is a product of the organic waste processing by earthworms. Secondly, it is a highly concentrated fertilizer that exceeds manure and compost by $4-8$ times in content of humic substances, contains a large number of enzymes, vitamins, soil antibiotics, plant growth hormones and other biologically active substances.

Gorova et al. (2016) claim that the timely application of vermicompost (biohumus), together with the implementation of agrochemical measures, provides the maximum transformation of the introduced organic fertilizers into humic substances and their fixing in the humus profile. It has a positive effect on the humus condition of the depleted and degraded soils, which is not always ensured by the application of traditional organic fertilizers (fresh litter, manure or peat) (Gorova et al., 2016). The disadvantages of using biohumus are high cost and insufficient production for large areas.

\section{Official Regulation Standards}

The humus balance study is part of the work to comply with the requirements of EU Regulation 1210/90 on the work of the European Environment Agency and the European Network of Observation and Information on the State of the Environment with a view to taking adequate measures to protect the environment and to further adjust it. The soil monitoring in the EU is carried out through several programs: ICP - Forest (international program for the assessment and monitoring of aerial forest pollution); ICP - IM 
(International Integrated Monitoring Program); FOREGS (Geological Forum).

For each soil type, the optimal humus content was established: for sod-podzolic sandy loam $1.8-2.0 \%$, gray forest sandy and loamy $-2.0-2.5$, dark gray forest and chernozem loamy-loamy $2.8-3.3$, typical loamy soils $-3.7-4.2 \%$. This humus content provides a fertility characteristic of a particular soil type. In order to achieve the optimum humus content, it is necessary to replenish the soil with the required amount of organic matter annually, and to ensure its deficit-free balance at the contents close to the optimum.

The dynamics of the weighted average humus content in the soil of the region was calculated using the materials of agrochemical certification. The agrochemical certification of agricultural lands was carried out in accordance with the current regulatory documents "Methods of continuous soil and agrochemical monitoring of agricultural ukrainian lands" (1994), and "Ecological and agrochemical certification of fields and agricultural land" (1996). The humus content in the soil was determined according to NSTU 4289: 2004.

The mathematical model of the humus content change in some soil volume $V$ can be described as follows:

Let $y(t)$ be the amount of humus at time $t(\mathrm{t} / \mathrm{ha}) ; y(t+\Delta t)-\mathrm{s}$, the amount of humus at time $t+\Delta t$; at the initial time $y(0)=y_{0}$, where: $y_{0}$ is the amount of humus at the initial time; $f(R, \delta)$ is some function of the humus balance and the type of crop (t/ha); $R$ is type of culture for planting, $\delta$ is balance of humus.

Then the humus change is proportional to the amount of humus at a given time and the function of the humus balance and the type of culture

$$
\begin{gathered}
V \frac{y(t+\Delta t)-y(t)}{\Delta t}= \\
=V \cdot k \cdot(y(t)+f(R, \delta))
\end{gathered}
$$

where: $k$-some proportionality factor.

At $\Delta \mathrm{t} \rightarrow 0$, we will get:

Then:

$$
\frac{d y}{d t}=k \cdot(y(t)+f(R, \delta))
$$

$$
\frac{d y}{y(t)+f(R, \delta)}=k d t
$$

From which $\ln |y(t)+f(R, \delta)|=k t+c$, where $c=$ const.

Then: $y(t)=c_{1} \cdot e^{k \cdot t}-f(R, \delta)$, where $c_{1}=e^{c}$.
From the initial condition $y(0)=y_{0}$ we will get $c_{1}=y_{0}+f(R, \delta)$.

Therefore, the humus content at time $t$ is equal to:

$$
y(t)=\left(y_{0}+f(R, \delta)\right) \cdot e^{k \cdot t}-f(R, \delta) .
$$

Applying this mathematical model to some input data, we get a graph of the humus content with a time (Fig. 1).

Integration of the obtained solution into the geoinformation-analytical system of organic farming. The software implementation task included the implementation of the aforementioned computer simulation mechanism for changing the humus state at a predetermined time interval, taking into account the costs of organic fertilizer application in the form of an e-calculator. Another important step was the integration of the newly created module into the existing geoinformationanalytical system of organic farming (Fig. 2).

The e-calculator module consists of two parts: the Backend part (ASP.NET MVC code, average crop fertility statistics, agrochemical soil indicators, etc.) and the Frontend part (html, css, java script). The Backend part implements the Web ARI mechanism for numerical calculations according to the GET and ROST requests of the Frontend part. On the client's side, the necessary requests are formed according to the client's needs: crop rotation, desired crops and fertilizer opportunities. There are two modes for modeling the humus state change: "Individual plan" and "Rationale for all scenarios". The desired mode is selected by switching the desired tab of the GUI module's GUI dialog box.

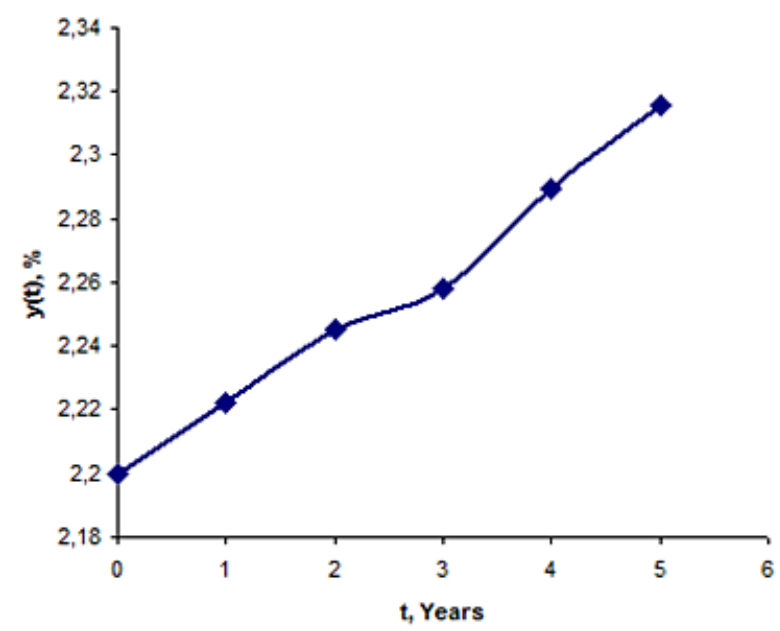

Fig. 1. Modelling the change of humus content in soil over time according to a mathematical model 


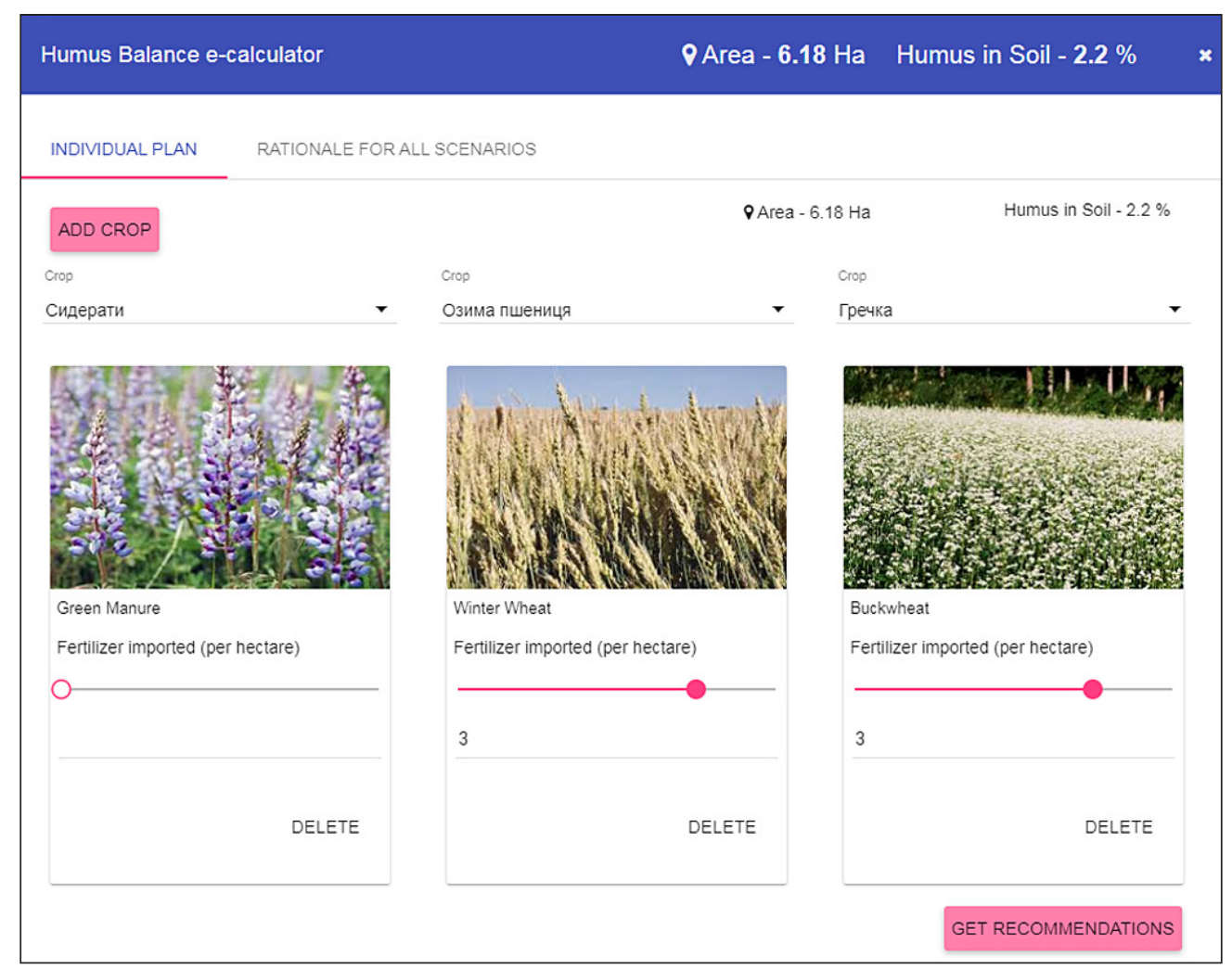

Fig. 2. Initialization of humus change simulation parameters in individual plan case

In the "Individual plan" mode, the user sets the crops and the amount of fertilizer for each year (Fig. 2). Then, by clicking on the "Get Recommendations" button, the system will generate a humus status change report for this particular scenario using a server-side numerical calculation according to the mathematical model above. Instead, the "Rationale for all scenarios" mode contains an automated calculation to justify all possible fertilizer scenarios in different years (Fig. 3). The user can choose the number of years to analyze and specify the amount of funds available for

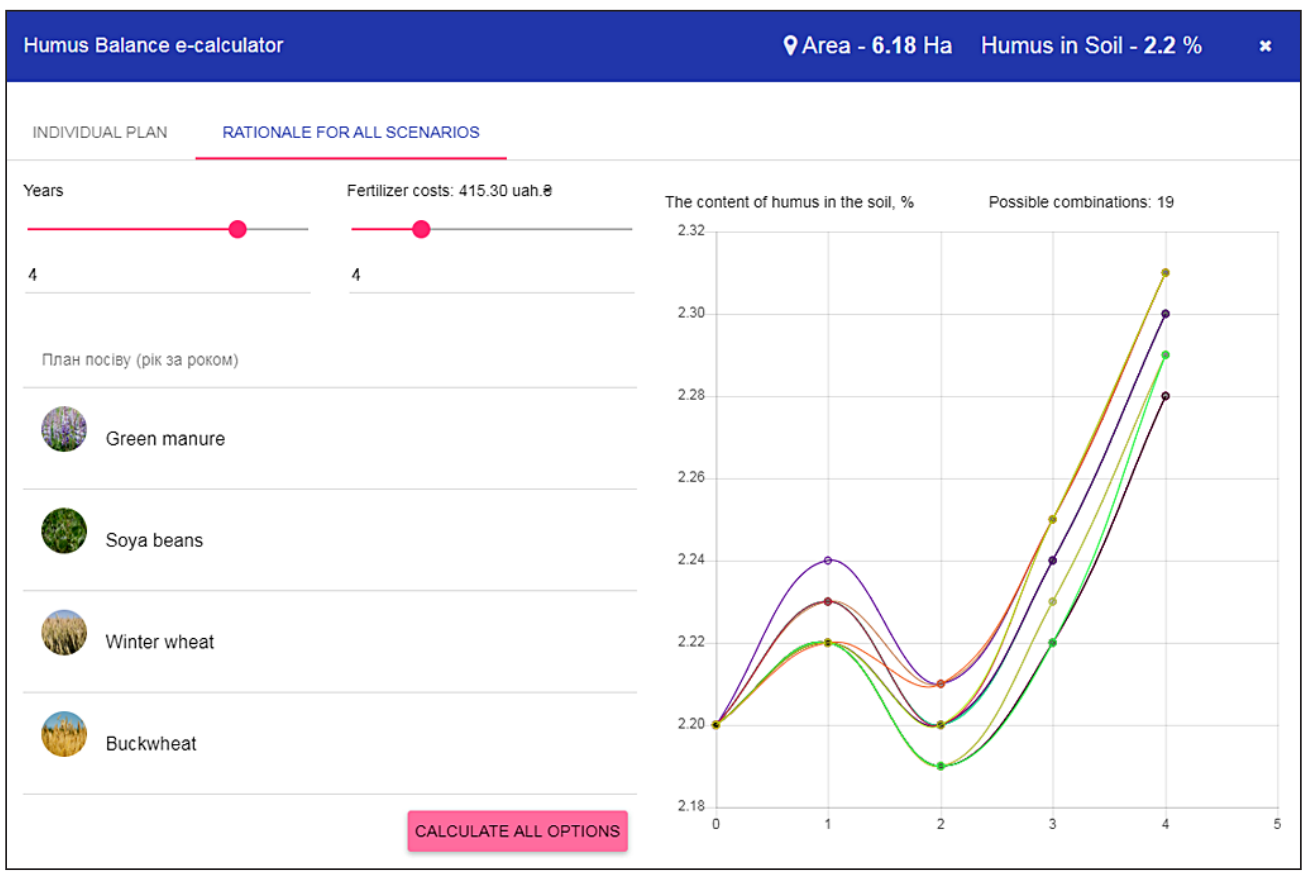

Fig. 3. A rationale for justifying all possible fertilizer scenarios in different years 
the organic fertilizer costs. Then, using the button "Calculate all options" launches the appropriate algorithm for computer simulation and eco-economic calculations of e-calculator. In this way, the user is able to choose the most suitable option from an economic and environmental point of view.

\section{RESULTS AND DISCUSSION}

Using the e-humus balance calculator, the user can independently set the cultivation order of crops in rotation, the amount of organic fertilizer (biohumus) application and as a result will receive the possible variants of the total humus content in the soil, for different volumes of organic fertilizer application (biohumus) siderates.

We have proposed crop rotation for the transition from traditional to organic land use with the condition of restoring the soil fertility. In calculating the amount of humus that can be formed, the main items of income are organic fertilizers (biohumus), plant residues, non-marketable (side) crop, side crops. The humus losses are due to mineralization.

Figure 4 presents 9 out of 1024 possible variants of the predicted humus content level in the soil for different fertilizer variants within the proposed crop rotation in the forest-steppe zone. As can be seen from the graph, post-harvest green fertilizers, along with straw, provide the largest number of nutrients to the soil. Due to the growing intensity of crop residues decomposition, soil fertility and crop yields are expected to increase next year. When growing soybeans, the soil receives the least amount of plant residues and, accordingly, humus that can form from them.

Option 1 on the graph at the end of the crop rotation shows the highest humus content in the soil, but this is subject to the maximum allowable amount of biohumus and correspondingly additional investments. The worst result was obtained in the proposed option \#9, but it does not imply any additional costs for the organic fertilizers application.

The testing of the e-calculator was carried out on the data of the Rivne branch of the state institution «Institute of Soil Conservation of Ukraine» for the last 40 years, taking into account the cultivated crops, the introduction of mineral and organic fertilizers. A prerequisite for preserving the soil fertility, compensating for the removal of nutrients from the crop, is the introduction of sufficient quantities of mineral and organic fertilizers.

Over the last 20 years, the acreage of Rivne region has changed (Fig. 5). There is a steady tendency towards a significant decrease in acreage under sugar beets, cereals and legumes. Instead, corn, soybeans and rapeseed are growing sowing areas. Such intensification of agricultural production, although accompanied by an increase in the amount of mineral fertilizers introduced, but does not adhere to the correct N: P: K ratio (1:0.33:0.30 at the optimum 1:0.8:1) and as a result, significant phosphorus and potassium deficiency in soil- is observed.

The dynamics of mineral fertilizer application in the farms of the Rivne region for 1971-2018 is shown in Figure 6.

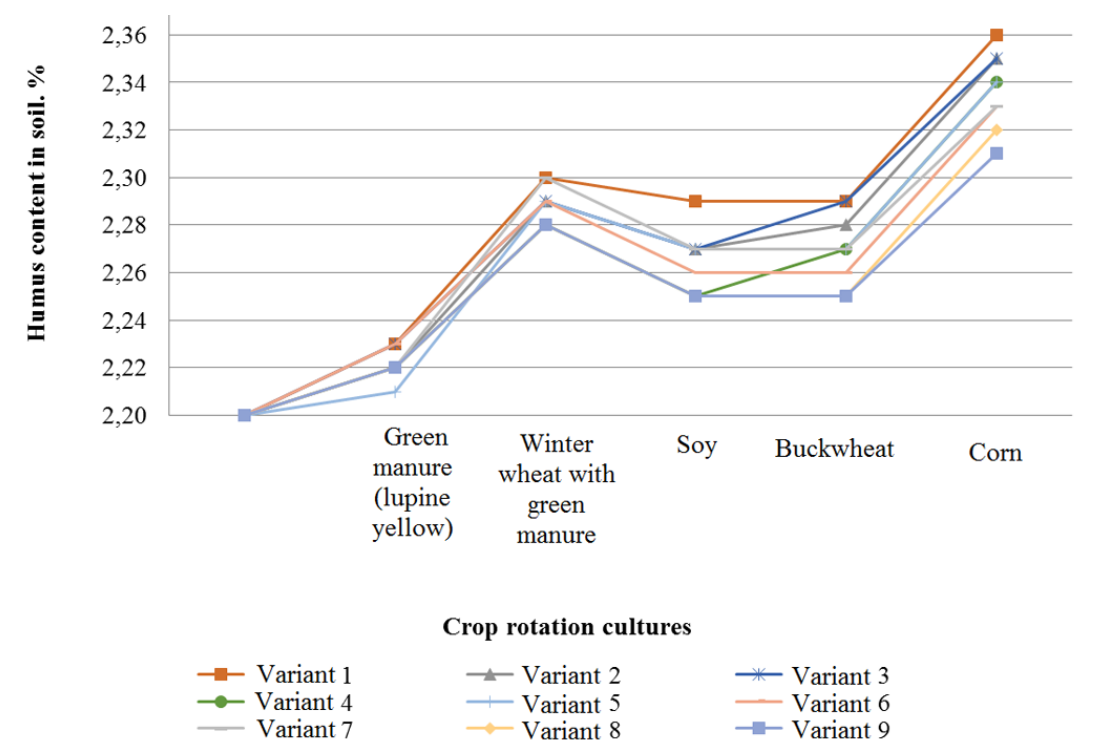

Fig. 4. The content of humus in the soil under different fertilizer options in the forest-steppe zone 


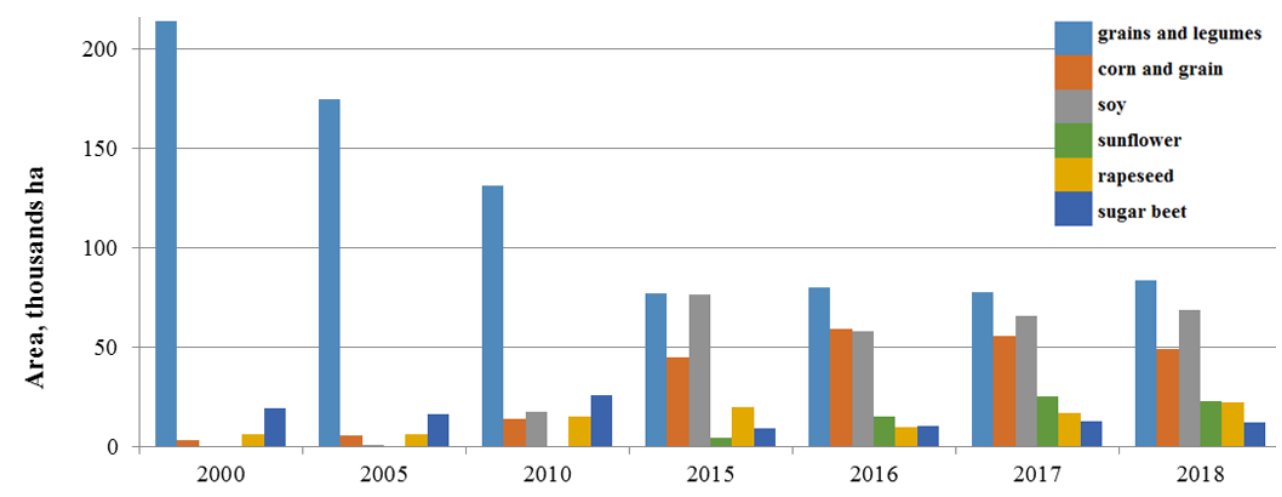

Figure 5. Distribution of crops under 2000-2018 years

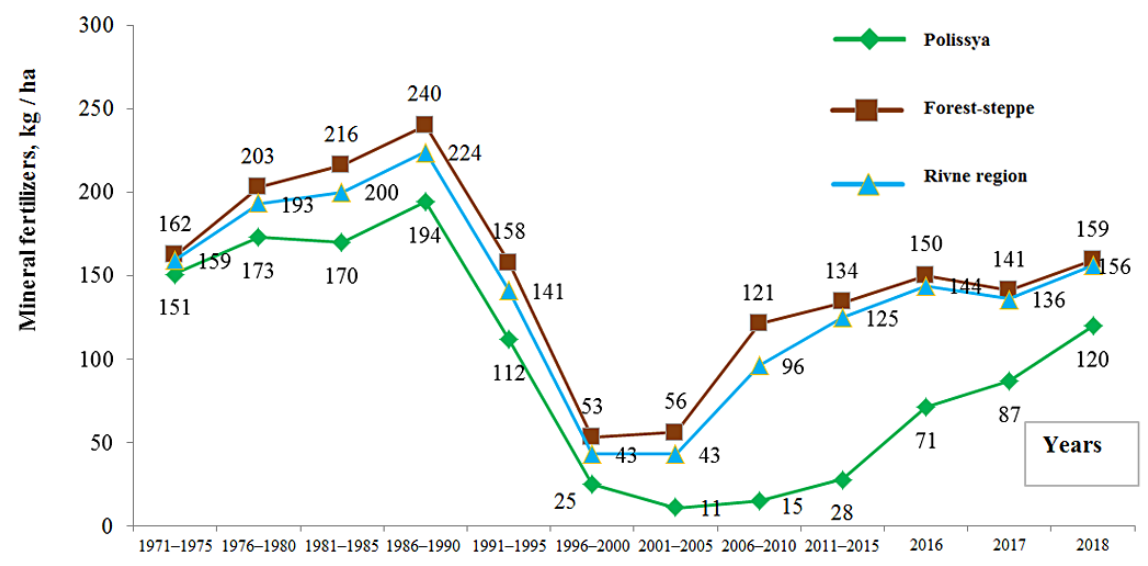

Fig. 6. Dynamics of mineral fertilizer application in the farms of Rivne region for 1971-2018 years

The situation with the application of organic fertilizers is much worse in the region. The dynamics for 1971-2018 are shown in Figure 7.

An alternative source of organic matter to the soil is the green manure plowing. The plowing dynamics of green manure in the farms of Rivne region for 2011-2018 is shown in Figure 8.

Although this is one of the cheapest measures to increase and stabilize the soil fertility, the plowing area and the green mass amount of green manure has decreased about three times in the last 3 years compared to 2011 .
Usually, there is a direct relationship between the humus content and the crop yield. Therefore, it is important to maintain a positive humus balance when farming and find ways to increase the organic matter content in the soil.

Over the last 5 years, there has been no stable but positive dynamics of the agricultural production with a positive or at least deficient balance of humus. This is due to the application of the agricultural biology elements: plowing of crop residues, use of green manure, new types of organic fertilizer.

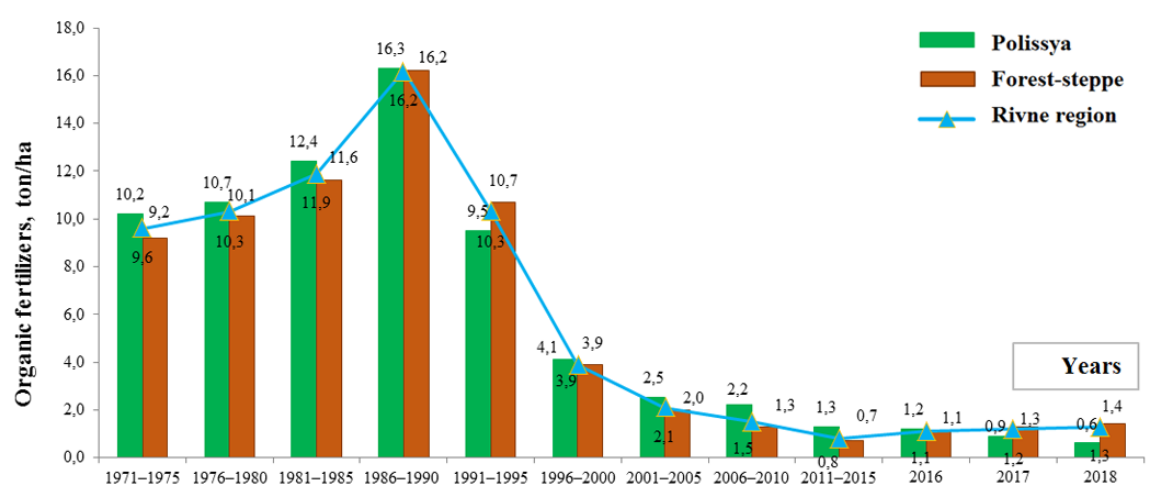

Fig. 7. Dynamics of organic fertilizer application in the farms of Rivne region for 1971-2017 years 


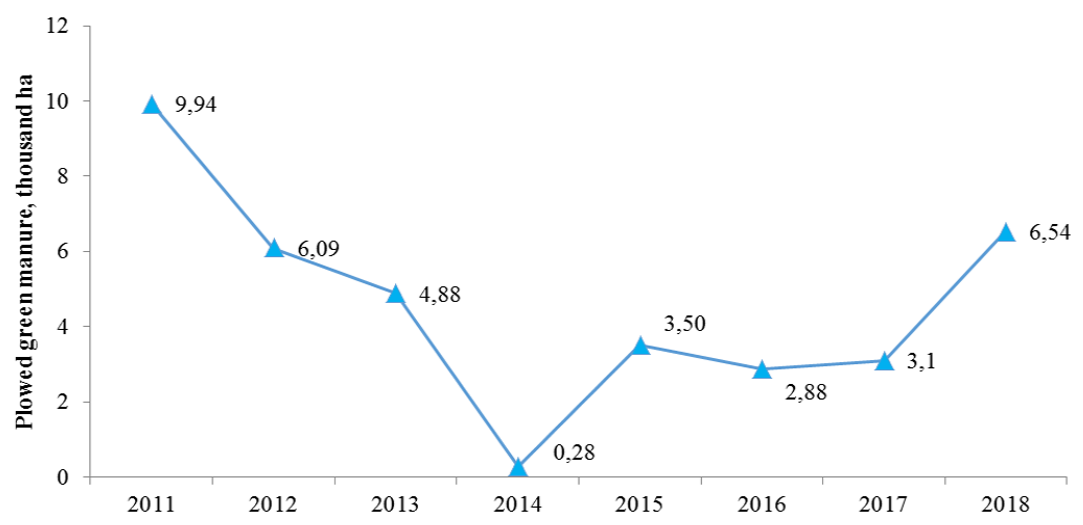

Fig. 8. Dynamics of green manure plowing in farms of Rivne region for 2011-2018 years

Table 1. The results of calculating the humus balance

\begin{tabular}{|c|c|c|c|c|c|c|c|c|c|}
\hline \multirow{3}{*}{$\begin{array}{l}\text { Alternation of crops } \\
\text { in rotation }\end{array}$} & \multirow{3}{*}{$\begin{array}{l}\text { The } \\
\text { presence of } \\
\text { humus in the } \\
\text { soil layer }\end{array}$} & \multicolumn{3}{|c|}{ Humus loss } & \multicolumn{3}{|c|}{ Humus accumulation } & \multirow{3}{*}{$\begin{array}{c}\text { Balance, } \\
+/-\end{array}$} & \multirow{3}{*}{$\begin{array}{l}\text { Total } \\
\text { humus }\end{array}$} \\
\hline & & \multirow[b]{2}{*}{ Total } & \multicolumn{2}{|c|}{ including } & \multirow[b]{2}{*}{ Total } & \multicolumn{2}{|c|}{ including } & & \\
\hline & & & mineralization & $\begin{array}{c}\text { washout } \\
\text { soil }\end{array}$ & & $\begin{array}{c}\text { plant } \\
\text { residues }\end{array}$ & $\begin{array}{l}\text { organic } \\
\text { fertilizers }\end{array}$ & & \\
\hline $\begin{array}{l}\text { 1. Lupine (annual } \\
\text { herbs, vica) } \\
\text { 2. Winter wheat } \\
\text { 3. Potatoes } \\
\text { 4. Silage corn. } \\
\text { 5. Winter wheat }\end{array}$ & 38.6 & 7.8 & 7.8 & - & 8.1 & 3.1 & 5 & +0.3 & 38.9 \\
\hline
\end{tabular}

In order to increase the agriculture stability on the basis of maximum utilization of potential and the introduction of a scientifically sound agriculture system in the $1980 \mathrm{~s}$, the branches of the Institute of Ukrzemproekt developed working projects for the crop production organization. The Table 1 shows the results of the humus balance calculation in fodder meadow grazing on a farm in the Kostopil region in the Rivne district. Practice shows that the application of organic fertilizers, the use of plant residues and annual grasses in rotation provides a positive humus balance, and therefore the restoration of soil fertility.

\section{CONCLUSION}

On the basis of a critical analysis of the literature, a method for calculating the biohumus balance from the point of view of organic land use and relevant ecological and economic indicators was proposed. This method is based on the selection of crop rotation for the transition from traditional to organic land use with the soil fertility restoration condition. In calculating the humus amount that can be formed, the main items of income are organic fertilizers (biohumus), plant residues, non-marketable (side) crop, side crops. The umus losses are due to mineralization. A mathematical model of the corresponding problem using differential equations was constructed and a numerical solution of the boundary value problem was found.

The proposed method of calculating humus balance was implemented in the form of an e-calculator module of the geoinformation-analytical organic agriculture system. Using the e-humus balance calculator, the user can independently set the order of crops cultivation in rotation, the organic fertilizer (biohumus) amount application and as a result will receive the possible variants of the total humus content in the soil, for different volumes of organic fertilizer application (biohumus) siderates. In order to receive detailed instructions on planned crops and the amount of fertilizer application, the user performs calculations annually in the "Individual plan" mode. Instead, the Rationale for All Scripts contains an automated calculation to justify all possible fertilizer scenarios in different years.

The e-calculator mechanism testing was carried out on the data of the Rivne branch of the Institute of Soil Protection of Ukraine for the last 40 years, taking into account the cultivated crops, introduction of mineral and organic fertilizers in the Ukraine's Rivne region. 
Using such a tool as an e-humus balance calculator will allow making management decisions for the efficient use of land resources through the widespread use of progressive resource-saving technologies that ensure a constant increase in the soil fertility and crop growth.

\section{Acknowledgement}

The publication contains the results of the research carried out within the project "Information-analytical system of organic farming and ensuring environmental sustainability of soils" (No. DR 0120U000235).

\section{REFERENCES}

1. Baluk S.A., Grekov V.O., Forest M.V., Komarista A.V. 2011. Calculation of humus and nutrient balance in Ukrainian agriculture at different levels of management. Kharkiv, City Printing House.

2. Bernard L., Kanellopoulos I., Annoni A., Smits P. 2005. The European geoportal — one step towards the establishment of a European Spatial Data Infrastructure. Computers, Environment and Urban Systems 29, 15-31.

3. Bogdanovich R.P., Oliynyk V.S. 2014. Influence of crop residues of short-rotation crop rotation crops on the content of moving humus substances in the black soil of a typical light-loamed Right-Bank Forest Steppe (in Ukrainian). Scientific papers of the Institute of bioenergy crops and sugar beet, 20-24.

4. Boyko P.I., Litvinov D.V., Cymbal E.S., Kudrya S.O. 2018. Principles of development of rotational rotation systems in Ukraine (in Ukrainian). Proceedings of the National Science Center Institute of Agriculture NAAS, 3-14.

5. Brock C., Franko U., Oberholzer H.-R. et al. 2013. Humus balancing in Central Europe-concepts, state of the art, and further challenges. Journal of Plant Nutrition and Soil Science 176, 3-11.

6. Brock C., Hoyer U., Leithold G., Hülsbergen K.J. 2012. The humus balance model (HU-MOD): A simple tool for the assessment of management change impact on soil organic matter levels in arable soils. Nutrient cycling in agroecosystems 92, 239-254.

7. Brock C., Oltmanns M., Leithold G. 2015. What do humus balances really tell about soil organic matter? Acta fytotechnica et zootechnica 18, 50-52.

8. Campbell E.E., Paustian K. 2015. Current developments in soil organic matter modeling and the expansion of model applications: a review. Environmental Research Letters 10, 123004.

9. Chaban V.I., Kovalenko V.Y., Klauso S.P. 2010.
Parameters of humus content in common black earth and forecast of its changes depending on agricultural production. Bulletin of the Grain Institute, 64-69.

10. Chertov O.G., Komarov A.S., Nadporozhskaya M., Bykhovets S.S., Zudin S.L. 2001. ROMUL-a model of forest soil organic matter dynamics as a substantial tool for forest ecosystem modeling. Ecological modelling 138, 289-308.

11. Franko U., Kolbe H., Thiel E., Ließ E. 2011. Multisite validation of a soil organic matter model for arable fields based on generally available input data. Geoderma 166, 119-134.

12. Gnatenko O.F., Kapstik M.V., Petrenko L.R., Vitvitsky S.V. 2005. Soil science with the basics of geology. Oranta.

13. Gorova A.I., Skvortsova T.V., Lisitska S.M. 2016. Restoration of humus condition and natural fertility of degraded black earths by means of vermicompost as organic fertilizer (in Ukrainian). Bulletin of Dnipropetrovsk State Agrarian and Economic University, 23-28.

14. Heitkamp F., Raupp J., Ludwig B. 2011. Soil organic matter pools and crop yields as affected by the rate of farmyard manure and use of biodynamic preparations in a sandy soil. Organic Agriculture 1:111-124.

15. Hénin S, Dupuis M. 1945. Essai de bilan de la matière organique du sol. Dudod.

16. Hrekov V.O., Datsko V.O. 2009. Rozrakhunok balansu humusu [Calculation of humus balance]. Posibnyk ukrainskoho khliboroba, 202-203.

17. Jaafar H.H., Woertz E. 2016. Agriculture as a funding source of ISIS: A GIS and remote sensing analysis. Food Policy 64, 14-25.

18. Kätterer T., Andrén O. 2001. The ICBM family of analytically solved models of soil carbon, nitrogen and microbial biomass dynamics-descriptions and application examples. Ecological Modelling 136, 191-207.

19. Kolbe H. 2010. Site-adjusted organic matter-balance method for use in arable farming systems. Journal of Plant Nutrition and Soil Science 173, 678-691.

20. Lebid E.M., Tsylyuryk O.I. 2014. Reproduction of black soil fertility and productivity of shortrotation steppe rotations depending on the soil mulching system (in Ukrainian). Bulletin of the Grain Institute, 8-14.

21. Leithold G., Hülsbergen K.J., Michel D., Schönmeier H. 1997. Humusbilanzierung-Methoden und Anwendung als Agrar-Umweltindikator. Initiativen zum Umweltschutz 5, 43-54.

22. Lisetskii F.N., Pichura V.I., Breus D.S. 2017. Use of geoinformation and neurotechnology to assess and to forecast the humus content variations in the steppe soils. Russian Agricultural Sciences 43, 157-161. 
23. Litvinova E. 2020. The principle of the green field - AgroTimes. [Internet]. Available from: https://agrotimes.ua/article/princip-zelenogo-polya/ (last consult: 2020/04/01).

24. Lykov, A., M. 1979. Towards a method for the calculation of soil humus balance in intensive agriculture (in Russian). TLC news, 14-20.

25. Maguire D.J., Longley P.A. 2005. The emergence of geoportals and their role in spatial data infrastructures. Computers, Environment and Urban Systems 29, 3-14.

26. Manzoni S., Porporato A. 2009. Soil carbon and nitrogen mineralization: theory and models across scales. Soil Biology and Biochemistry 41, 1355-1379.

27. Medvedev V.V. 2007. Soil heterogeneity and precision agriculture (in Russian). Part I. Introduction to the problem. Kharkov Ed 13.

28. Mishra A.K., Deep S., Choudhary A. 2015. Identification of suitable sites for organic farming using AHP \& GIS. The Egyptian Journal of Remote Sensing and Space Science 18, 181-193.

29. Montgomery B., Dragićević S., Dujmović J., Schmidt M. 2016. A GIS-based Logic Scoring of Preference method for evaluation of land capability and suitability for agriculture. Computers and Electronics in Agriculture 124, 340-353.

30. Morozov V.V., Plotkin S. I ., Polyakov M.G. 2007. Modeling and forecasting for geoinformation systems projects: Tutorial book. Kherson: KSU Publishing House.

31. Oliver Y.M., Gabriel A.J., Germanovich O.M., Sivak L.M. 2014. Dynamics of the labile part of the humus of light-gray forest surface-covered soil, depending on long fertilization and periodic liming (in Ukraine). Foothills and mountain farming and animal husbandry, 141-147.

32. Oumenskou H., El Baghdadi M., Barakat A. et al. 2018. Assessment of the heavy metal contamination using GIS-based approach and pollution indices in agricultural soils from Beni Amir irrigated perimeter, Tadla plain, Morocco. Arabian Journal of Geosciences 11, 405.

33. Pichura V.I., Potravka L.A., Dudiak N.V., Skrypchuk P.M., Stratichuk N.V. 2019. Retrospective and Forecast of Heterochronal Climatic Fluctuations Within Territory of Dnieper Basin. Indian Journal of Ecology 46, 402-407.

34. Romashchenko M.I, Rachinska E.S, Shevchenko, A.M. (Eds). 2005. Information support for irrigated agriculture. The concept, structure, methodology of the organization (in Ukrainian). Kyiv: Agrarian science.

35. Schulz F., Brock C., Schmidt H., Franz K.-P., Leithold G. 2014. Development of soil organic matter stocks under different farm types and tillage systems in the Organic Arable Farming Experiment Gladbacherhof. Archives of Agronomy and Soil Science 60, 313-326.

36. Shostak L., Boiko M., Stepanchenko O., Kozhushko O. 2019. Analysis of soil organic matter transformation dynamics models. Informatyka, Automatyka, Pomiary w Gospodarce i Ochronie Srodowiska 9, 40-45.

37. Skrylnik E.V., Shevchenko M.V., Popirny M.A. 2017. Influence of soil tillage systems on the distribution and quality of humic soil of typical black soil (in Ukrainian). Fundamental and Applied Soil Science 18, 46-54.

38. Skrypchuk P.M., Shcherbakova O.Y., Suduk O.Y., Rybak V.V. 2020. Renewable Biomass Growing in Low Fertile Land and Forest-Steppe of Ukraine. Indian Journal of Ecology 47, 155-163.

39. Skrypchuk PM. (Ed). 2018a. Information support for the development of organic agriculture. Rivne: NUWEE.

40. Skrypchuk P.M. (Ed). 2018b. Organizational and economic principles of information support of the economy. Rivne: NUWEE.

41. Skrypchuk P.M. (Ed). 2019. Geo-management in organic agriculture. Podhajska, Slovensko: Europsky institut dalsieho vzdelavania.

42. Tait M.G. 2005. Implementing geoportals: applications of distributed GIS. Computers, Environment and Urban Systems 29, 33-47.

43. Vlasyuk A., Zhukovska N., Zhukovskyy V., Hesham R. 2020a. Mathematical Modelling of Spatial Deformation Process of Soil Massif with Free Surface. Advances in intelligent systems and computing IV 1080, 107-120.

44. Vlasyuk A., Zhukovskyy V., Zhukovska N., Pinchuk O., Rajab H. 2020b. Mathematical Modeling of Heat, Mass and Moisture Transfer in Catalytic Porous Media. WSEAS Transactions on Applied and Theoretical Mechanic 15, 52-59.

45. Vlasyuk A.P., Borowik B., Zhukovska, N.A., Zhukovskyy V.V., Karpinskyi V. 2018a. Computer modelling of heat and mass transfer effect on the threedimensional stressed-strained state of soil massif. 18th International Multidisciplinary Scientific Geoconference SGEM 2018 18, 153-160.

46. Vlasyuk A.P., Kochan R.V., Zhukovskyy V.V., Zhukovska N.A. 2018b. Mathematical and computer modeling of contaminant migration to filter trap in two-dimensional nonlinear case. 18th International Multidisciplinary Scientific Geoconference SGEM 2018 18, 293-300.

47. Volkogon V.V., Berdnikov O.M., Tokmakova L.M. et al. 2016. Orientation of processes of biological transformation of nitrogen in the rhizospheric soil of potato plants under the action of biotic and abiotic factors of crop fertilizer (in Ukrainian). Agricultural Microbiology, 3-9. 